(C) 2017

\author{
Войтенко С. Л., доктор сільськогосподарських наук
}

Полтавська державна аграрна академія

\title{
МЕТОДИКА КОМПЛЕКСНОЇ ОЦІНКИ КНУРІВ І СВИНОМАТОК ЗА ЯКІСТЮ ПОТОМСТВА
}

\section{Рецензент - доктор сільськогосподарських наук А. А. Поліщук}

Висвітлені основні підходи до комплексної оиінки кнурів і свиноматок за якістю потомства в умовах ферми (господарства). Запропоновано визначати иінність кнурів і свиноматок не лише за відгодівельними і м'ясними ознаками їх потомків, але й за власною продуктивністю останніх. Описано послідовність добору тварин для їх випробовування в умовах ферми за власною продуктивністю та відгодівельними і м'ясними ознаками з визначенням балу за кожну із ознак. Для комплексної оцінки кнурів і свиноматок за якістю потомства запропоновано використовувати розроблений оціночний індекс, в основі якого середня величина усіх досліджуваних під час випробовування ознак у сибсів і напівсибсів.

Запропонована нова методика оцінки кнурів і свиноматок за якістю потомства дасть змогу оиінити не лише племінних свиней, але помісних $i$ гібридних, застосовувати єдину методику оцінки тварин основного стада у господарствах різної категорії, обходитися без станцій контрольної відгодівлі свиней та визначити иінність кнура і свиноматки за якістю потомства на основі розробленого оціночного індексу.

Ключові слова: методика, свині, випробовування в умовах ферми, комплексна оцінка, індекс.

Постановка проблеми. У практиці вітчизняного свинарства для оцінювання чистопородних племінних свиней в суб'єктах племінної справи передбачена оцінка ремонтного молодняку за власною продуктивністю (фенотипом) та кнурів і свиноматок - за якістю потомства (генотипом) $[4,5,7]$. Тобто кнур чи свиноматка, які використовуються в племінному стаді, оцінюються під час свого вирощування за віком досягнення живої маси 100 кг та товщиною шпику на рівні 6-7-го грудних хребців (прижиттєво), а також за відгодівельними та м'ясними ознаками своїх потомків. Проте загальноприйняті методи оцінки свиней не передбачають оцінки гібридного молодняку, а лише чистопородного, а також не містять узагальнюючих даних щодо оцінки кнурів і свиноматок за власною продуктивністю потомків, їх відгодівельними та м'ясними ознаками. Тобто наразі відсутня комплексна оцінка свиней племінної частини стада за фенотипом і генотипом їх потомків. Крім того, в доступних засобах масової інформації, включаючи літературні джерела та законодавчу базу галузі свинарства, не висвітлені можливості проведення випробовування свиней в умовах ферми, де вони утримуються. У зв'язку з чим виникає нагальна потреба в розробці методики оцінювання кнурів і свиноматок свиней за якістю потомства в тих умовах, де вони розводяться.

Аналіз останніх досліджень і публікацій, у яких започатковано розв'язання проблеми. Аналіз зведених звітів по бонітуванню свиней в суб'єктах племінної справи $[1,2]$ та дані Державного племінного реєстру за низкою років підтверджують оцінювання чистопородного ремонтного молодняку за власною продуктивністю в умовах ферм (господарств). Проте у вищевказаних інформаційних базах практично відсутні дані щодо оцінки кнурів і свиноматок за якістю потомства в умовах станцій контрольної відгодівлі 3 огляду на бездіяльність останніх та їх незначну кількість. У кращому випадку оцінювання кнурів і свиноматок за генотипом проводиться в умовах племінних господарств без дотримання єдиної методики, що ставить під сумнів правильність одержаних даних та ефективність селекції за бажаними ознаками продуктивності.

Загальновідомо, що зараз селекція свиней спрямована на покращання відгодівельних i м'ясних ознак, а отже виявлення найбільш високопродуктивних тварин та їх підбір має актуальність і практичну цінність. При цьому добір свиней тільки за ознаками власної продуктивності не завжди узгоджується 3 якістю їх потомків. Можливість комбінованої чи комплексної оцінки свиней за генотипом і фенотипом, яка була запропонована раніше, не знайшла широкого застосування 3 огляду на низку недоліків $[3,6,8$, 9]. Саме тому слід переходити на інші, більш реальні методи оцінки та добору свиней.

Мета досліджень - розробити методику оцінки кнурів і свиноматок за якістю їх потомків, яка поза відгодівельними і м'ясними ознаками потомків включала б і дані за їх власну продуктивність 3 визначенням цих показників в умовах однісї ферми (господарства).

Завдання досліджень - прописати основні вимоги до випробування свиней в умовах ферми 


\section{СІЛЬСЬКЕ ГОСПОДАРСТВО. ТВАРИННИЦТВО}

(господарства) та розробити оціночний індекс кнурів і свиноматок за якістю потомства.

Матеріал і методи досліджень - розробка нової методики комплексної оцінки кнурів і свиноматок за якістю потомства здійснена за використання наявної законодавчої бази галузі свинарства та результатів власних досліджень.

Результати досліджень. Оцінка чистопородного, помісного і гібридного молодняку за власною продуктивністю, відгодівельними і м'ясними ознаками проводиться в умовах однієї ферми (господарства).

Кнур оцінюється за якістю потомства, яке походить не менше, ніж від двох свиноматок провідної групи 3 двома і більше опоросами. Відібраний для випробування молодняк, який походить від одного кнура, розділяють на дві групи: одна 3 яких буде випробовуватися в умовах ферми за власною продуктивністю, а інша - теж в умовах цієї ж ферми, але за відгодівельними та м'ясними ознаками. На вирощування добирають лише кнурців і свинок, а для відгодівлі - кнурців, свинок і кастратів.

Первинний облік власної продуктивності молодняку та оцінки кнурів і свиноматок за якістю потомства проводять за формами, які наведені в Інструкції 3 ведення племінного обліку у свинарстві [4].

Випробування молодняка за власною продуктивністю в умовах ферми здійснюється наступним чином:

Молодняк свиней для оцінювання за власною продуктивністю добирають 3 попередньо намічених гнізд свиноматок провідної групи до їх відлучення від маток.

Після відлучення поросят від свиноматок формують окремі групи із кнурців і свинок, аналогів за віком та живою масою, яких дорощують в умовах ферми до живої маси 28-30 кг.

У разі досягнення тваринами живої маси 2830 кг розпочинають обліковий період, який триває до досягнення тваринами живої маси 100 кг.

Численність свиней під час вирощування в одному станку може становити 10-30 голів, а різниця у віці між ними повинна бути не більше 10-15 днів.

Рівень годівлі свиней повинен забезпечувати середньодобові прирости за період вирощування на рівні 550-600 г. За можливості під час вирощування свиней використовують моціон.

За період вирощування по кожній тварині визначають вік досягнення живої маси 100 кг, як різницю між датою досягнення живої маси 100 кг та датою народження, а також товщину шпику на рівні 6-7-го грудних хребців мірними приладами, відступивши 5 см вправо або вліво від лінії остистих відростків грудних хребців й подають їх у балах.

За необхідності можуть бути визначені й інші селекційні показники.

Допускається зняття тварин з вирощування за живої маси 95-105 кг, але за обов'язкового перерахунку віку досягнення живої маси 100 кг і товщини шпику на живу масу 100 кг, згідно 3 відповідними поправними коефіцієнтами [4].

За кожну ознаку виставляють бал, як середній показник по групі досліджуваних тварин одного кнура чи свиноматки. При цьому показники досліджуваних ознак для племінних свиней порівнюють із вимогами Інструкції по бонітуванню свиней, враховуючи належність тварин до відповідної групи (перша, друга чи третя), а для помісних і гібридних свиней рекомендовано порівнювати дані із батьківською породою. Якщо батьківської породи немає в Інструкції з бонітування свиней, - то з материнською породою.

Випробування молодняка за відгодівельними та м'ясними ознаками в умовах ферми здійснюється наступним чином:

Для оцінки молодняка за відгодівельними та м'ясними ознаками в умовах ферми добирають свиней у віці 85-90 днів з таким розрахунком, щоб потомки походили від одного кнура і двох або трьох свиноматок і їх було не менше 12 голів. Тварини повинні бути сибсами чи напівсибсами тих тварин, яких випробовують за власною продуктивністю в умовах цієї ж ферми.

Кількість свинок повинна становити $50 \%$ від відібраних тварин, а кнурців і кастратів, відповідно по $25 \%$.

Обліковий період розпочинається за середнього віку тварин 90 днів і закінчується за досягнення ними живої маси 100 кг.

Для оцінки свиней за відгодівельними i м'ясними ознаками в умовах ферми виділяють окреме приміщення чи секцію у приміщенні, яке обладнують годівницями та поїлками, згідно 3 загальними технологічними вимогами.

В окремих станках розміщують сибсів та напівсибсів за кнуром - по 4, 6, 12 чи більше голів у станку за умови аналогічності їх походження.

Утримання тварин під час відгодівлі - безвигульне.

Годівля тварин вволю з тим, щоб забезпечувати прояв їх генетичного потенціалу. Свині повинні мати вільний доступ до води.

У разі досягнення тваринами живої маси 95100 кг їх знімають з відгодівлі та відбирають для подальшого відтворення чи забою.

За період відгодівлі свиней в умовах ферми 


\section{СІЛЬСЬКЕ ГОСПОДАРСТВО. ТВАРИННИЦТВО}

визначають витрати корму на 1 кг приросту, вік досягнення живої маси 100 кг та інші показники.

Для оцінювання кнурів і свиноматок за відгодівельними ознаками їх потомства визначають середні показники по групі тварин у балах.

Для оцінювання кнурів i свиноматок за м'ясними ознаками потомства відбирають усіх кастратів та $25 \%$ свинок із $50 \%$ поставлених на відгодівлю i забивають в умовах бойні чи м'ясокомбінату. У забитих свиней визначають довжину півтуші та товщину шпику, а також інші селекційні ознаки.

Якщо молодняк зняли 3 відгодівлі живою масою 95-105 кг проводиться перерахунок показників відгодівельних і м'ясних ознак на живу масу 100 кг [4].

Кнурців і свинок, які були оцінені за відгодівельними ознаками і не підлягали забою, використовують для відтворення стада.

Для оцінювання кнурів i свиноматок за м'ясними ознаками їх потомства визначають середні показники по групі тварин у балах.

Показники досліджуваних ознак для племінних свиней порівнюють із вимогами Інструкції по бонітуванню свиней, враховуючи належність тварин до відповідної групи (перша, друга чи третя), а для помісних і гібридних свиней рекомендовано порівнювати дані із батьківською породою. Якщо батьківської породи немає в Інструкції з бонітування свиней, - то з материнською породою.

Комплексну оцінку кнурів i свиноматок за якістю потомків пропонуємо проводити за використання розробленого нами оціночного індексу.

Розрахунки оціночного індексу кнурів і свиноматок за фенотипом потомків, а також їх відгодівельними та м'ясними ознаками (IKC) проводять за формулою:

IKC $=\left(a_{1}+a_{2}+\ldots+a_{n}+b_{1+} b_{2}+\ldots+b_{n}+c_{1}+c_{2}\right.$ $\left.\ldots+\mathrm{c}_{\mathrm{n}}\right): \mathrm{n}$, де

\section{БІБЛІОГРАФІЯ}

1. Войтенко С. Л. Состояние племенного свиноводства Украины / С. Л. Войтенко, Л. В. Вишневский // «Современные проблемы и научное обеспечение инновационного развития свиноводства» : Сб. научных статей по материалам XXIII Международной научно-практической конференции (21-23 июля 2016 г.). - М. : Лесные Поляны, 2016. - С. 19-26.

2. Гладій M. В. Генеалогічна структура та продуктивність вирощеного молодняка сучасних порід свиней України / М. В. Гладій, С. Л. Войтенко, Л.В. Вишневський // Тваринництво України. - 2014. - №11. - С. 10-14.

3. Добір свиней за власною продуктивністю
IКС - індекс кнурів і свиноматок за якістю потомків;

$\mathrm{a}_{1+} \mathrm{a}_{2}, \mathrm{a}_{\mathrm{n}}$ - бал за відповідну ознаку власної продуктивності потомків;

$b_{1+} b_{2}, b_{n}-$ бал за відповідну ознаку відгодівельних ознак потомків;

$\mathrm{c}_{1}, \mathrm{c}_{2}, \mathrm{c}_{\mathrm{n}}$ - бал за відповідну ознаку м'ясних ознак потомків;

n - кількість ознак продуктивності.

Наприклад, потомки кнура за власною продуктивністю та відгодівельними і м'ясними ознаками оцінені:

- вік досягнення живої маси 100 кг під час вирощування - 5 балів;

- товщина шпику на рівні 6-7-го грудних хребців (прижиттєво) - 4 бали;

- довжина тулубу (прижиттєво) - 5 балів;

- вік досягнення живої маси 100 кг на відгодівлі - 5 балів;

- товщина шпику на рівні 6-7-го грудних хребців після забою - 5 балів

- довжина півтуші після забою - 5 балів.

Індекс кнурів і свиноматок за якістю потомків у даному випадку буде становити:

$\mathrm{IKC}=(5+4+5+5+5+5): 6=4,8$ балів $\approx 5$ балів

Для зручності користування запропонований індекс слід подавати цілим числом, для чого використати загальновживані правила округлення числа. Він не повинен бути вищим за 5 балів.

Висновок. Запропонована нова методика оцінки кнурів і свиноматок за якістю потомства дасть змогу оцінити не лише племінних свиней, але помісних і гібридних, застосовувати єдину методику оцінки тварин основного стада у господарствах різної категорії, обходитися без станцій контрольної відгодівлі свиней та визначити цінність кнура і свиноматки за якістю потомства на основі розробленого оціночного індексу.

та якістю нащадків / [Вишневський Л. В., Войтенко С. Л., Гиря В. М. та ін.] // Міжвід. тематичний науковий збірник «Свинарство». - 2008. - №56. - С. 25-28

4. Інструкція з бонітування свиней; Інструкція 3 ведення племінного обліку у свинарстві. - К. : Видавничо-поліграфічний центр «Київський університет», 2003. - 64 с.

5. Методика оцінки кнурів і свиноматок за якістю потомства в умовах племінних заводів i племінних репродукторів / [Березовський М. Д., Хатько I. В., Білоус О. В. та ін.]. - Полтава, 2004. $-10 \mathrm{c}$. 


\section{СІЛЬСЬКЕ ГОСПОДАРСТВО. ТВАРИННИЦТВО}

6. Мухарев В. Оценка хряков различными методами / В. Мухарев // Свиноводство. - 1991. №6. - C. 18-19.

7. Наказ Мінагрополітики України № 290 від 06.06.2004 р. «Про затвердження інструкції 3 оцінки кнурів і свиноматок за якістю потомків в умовах спеціалізованої контрольновипробувальної станції».
8. Титов И. С. Оценка свиней по генотипу разными методами / И. С. Титов, С. Ю. Дементьєва // Зоотехнія. - 1991. - №12. - С. 7-9.

9. Филатов А. И. О совмещении оценки хряков по фенотипу и генотипу / А. И. Филатов, Г. А. Бочоришвили // Свиноводство. - 1991. №6. - C. 19-20. 